\title{
Efforts To Improve Students' Multiple Intelligence In Dealing With Era 4.0 On The Subject of Basic Chemistry
}

\author{
Ayu Rahmi1,a Coryna Oktaviani 1 ,b \& Sirry Alvina ${ }^{1, c}$ \\ 1Department of Chemistry Education, Malikussaleh University, Aceh Utara, 24355, Indonesia \\ a aiu.rahmi@gmail.com; b coryna.oktaviani@unimal.ac.id; c sirry.alvina@yahoo.com \\ ${ }^{*}$ Corresponding Author:
}

How to Cite : Rahmi, A., Oktaviani, C., Alvina, S. (2020). Efforts To Improve Students' Multiple Intelligence In Dealing With Era 4.0 On The Subject of Basic Chemistry. International Journal for Educational and Vocational Studies, 2 (1), 149-152. DOI: https://doi.org/10.29103/ijevs.v2i1.1878

\section{ARTICLE HISTORY}

Received: 26 September 2019

Revised: 22 November 2019

Accepted: 12 December2019

\section{KEYWORDS}

Multiple Intelligence

Era 4.0

Basic Chemistry

\begin{abstract}
The study on efforts to improve students' multiple Intelligence in dealing with 4.0 era in basic chemistry courses was conducted with the aim of knowing whether the questions can be developing Multiple Intelligence and whether there was an increase in Multiple Intelligence on the student's of Faculty of Teachers Training and Education at Malikussaleh University. This study was carried out using Research and Development method or known as R\&D which consists of four stages, namely the development of test questions, standardization and revision of test questions, as well as evaluation on the developed test result. The location of the study was at Faculty of Teachers Training and Education at the Malikussaleh University, located at Main Campus of Reuleut starting on the July to September 2019 with a population of all the students of Faculty of Teachers Training and Education at the Malikussaleh University. The samples in this study were students of the Department of Chemistry Education in semester 2, 4, and 6 with 20 students for each term and were taken by means of purposive sampling. Based on the results of the R\&D stages, qualitative and quantitative data were obtained, then the data were analyzed using the comparison and percentage formulas. The results obtained was that there was an increase in the percentage of the value of $\mathrm{N}$-gain by $82 \%$. These results indicated a high increase from before to afterwards the treatment was implemented in this study.
\end{abstract}

This is an open access article under the CC-BY-SA license.

\section{INTRODUCTION}

Teaching and learning activities are the most important activities in the world of education. The achievement of educational success is greatly influenced by the learning process. This process involves communication between educators (teachers) and learners (students). In learning activities, the teacher will deal with students with a variety of characters, so as to find out the extent of students' abilities after learning, the teacher needs to provide tests as a measurement tool. From this test result, it will be known which learning objectives that are achieved by the students. The most important thing from the learning process is how students are able to master subject matter optimally (Hidayat, 2011). Mastery of the material can be seen from the extent to which students are able to receive lessons and how well the ability of students to understand the subject matter.
Several factors affect student learning outcomes including subject matter, delivery of material by the teacher, learning models, as well as facilities and infrastructure. Students' level of intelligence also varies, such as low, medium, and high, which also affect student learning outcomes. Students who have a low intelligence level will likely find it difficult to understand the material while students who have a high intelligence level mostly understand the material faster and easier.

In recent years, the level of student intelligence is not only seen from the results of cognitive learning, but also has spread to several aspects beyond cognitive factors. Since then, several theories of intelligence have emerged that are not only related to cognitive, such as emotional, spiritual, social, and so on. Tyler (1956) revealed the link of intelligence toward the reasoning knowledge, the ability to act effectively in dealing with new situations and the ability to obtain and use information 
appropriately. Furthermore, Sorenson (1977) states that a person with high intelligence will quickly understand the situation at hand and has quick thinking.

In 1983 Howard Gardner developed a theory known as Multiple Intelligence. He defines intelligence as a biopsychological potential, and under what circumstances a person is considered intelligent is determined from genetic factors and psychological traits, ranging from cognitive factors to personality tendencies (Gardner: 1993). This definition of intelligence made by Gardner not only views intelligence as a cognitive ability but that ability is integrated with the characteristics of his personality which in daily life are used to solve problems and create products. In accordance with his theory, the measurement of multiple intelligences is inseparable from the measurement of the psychological aspects of humans.

The assessment of chemistry learning outcomes in schools mostly only focuses on cognitive aspects, whereas for the students' affective and psychomotor aspects are rarely done. The questions given to students also do not contain questions that can develop their Multiple Intelligence. This is known from the results of initial observations made at several schools in North Aceh and Lhokseumawe. The teacher rarely assesses the affective aspect because of the limited time in the learning process, whereas the psychomotor assessment is rarely done because of inadequate facilities and infrastructure for chemistry lessons.

The industrial revolution 4.0 is the fourth phase of the development of the industrial revolution which began in the 18th century. In this phase, technological advances occur on a large scale in all fields. Meanwhile, the ownership of smart devices in various parts of the world leads to a degree of interrelation with one another. This 4.0 era also changed the way of viewing education. The changes that occur are not only the way of teaching, but also which is far more essential, the change in the way of viewing the concept of education itself (Sukartono, 2018).

As future teacher candidates, students of Teacher Training and Education Faculty (FKIP) of Malikussaleh University, are required to have high intelligence. The intelligence here is not only limited to cognitive, but also the ability to solve a problem through several ways that are related to the power of thought and cognitive metamorphosis (Multiple Intelligence). With their Multiple Intelligence, they are expected to be able to carry out the teaching and learning process in class as much as possible, whether it is the way they teach, how they view the concepts or material to be taught, as well as how they prepare questions to be given to measure student learning outcomes. As in this case, it is expected that in the subject matter of chemistry, the learning objectives can be achieved which can indirectly improve the quality of education. From the results of the initial observations described above, students are also expected to be able to manage their time as best as they can and be able to take advantage of their surroundings to cover the lack of facilities and infrastructure in the learning process. Based on the background described above, the writer wants to conduct research with the aim of finding out whether the questions on the Basic Chemistry material contain questions that can develop Multiple Intelligence FKIP Malikussaleh University students and find out whether there is an increase in Multiple Intelligence in FKIP Malikussaleh University students as preparation for facing the 4.0 era in the Basic Chemistry course.

\section{METHODS}

Efforts to improve the Multiple Intelligence of students in facing 4.0 era in basic chemistry courses are carried out by the Research and Development method or known as R\&D. This research was conducted with the stages included the analysis of the questions that have been prepared, the development of test questions, standardization and revision of test questions, and evaluation of the developed test results. The location of the research was at Malikussaleh University, located at Jl. Cot Teungku Nie, Reuleut, Kec. Muara Batu, North Aceh from July to September 2019.

The population given the treatment was all students of FKIP Malikussaleh University, while for the sample were 20 chemistry students in semester 2, 4, and 6 each and they were taken by means of purposive sampling. Based on the results of the implemented R\&D stages, qualitative and quantitative data were obtained. These data are obtained from the standardization of test questions that have been developed and also the results of students' answers to the test questions that they have completed. The next step, the data is analyzed using a comparison and percentage formula.

\section{RESULTS AND DISCUSSION}

\subsection{Result on the Analysis of the Questions}

The first thing to do in this research was to analyze the questions on the Basic Chemistry material that would be used in research. Through this analysis the researchers would find out whether the questions available contained questions in accordance with the criteria that can develop Multiple Intelligence of FKIP students at Malikussaleh University. However, to find out whether there was an increase in students' Multiple Intelligence in preparation for facing the 4.0 era, students were given a pre-test to determine their initial knowledge in Basic Chemistry material. The questions used for this initial test were obtained from the analysis of 32 items of question. Among these questions, there are 16 questions which are known to be able to develop students' Multiple Intelligence.

Based on the results of the test questions that had been given to the research sample, the test scores obtained were varied with the highest and lowest values respectively are 75 and 25 . Thus the score can be 
classified into 3 categories, namely high categories with a range of values $80-100$, medium category with a range of values $65-79$, and a low category with a range of values less than 65 (Purwanto, 2004: 76). In accordance with students' initial test scores, the frequency scores can be seen in full in Table 1.

Table 1. Distribution of Student Initial Test Scores

\begin{tabular}{lccc}
\hline \multicolumn{1}{c}{ Category } & Score & Frequency & Percentage (\%) \\
\hline High & $80-100$ & 0 & 0 \\
\hline Medium & $65-79$ & 18 & 30 \\
\hline Low & $<65$ & 42 & 70 \\
\hline
\end{tabular}

The results of the data seen in Table 1 show that the categories of scores obtained from the initial student test results were $30 \%$ in the medium category and $70 \%$ in the low category. That is, of all students, only a few of them have good enough initial knowledge on Basic Chemistry material.

\subsection{Results of Development, Standardization and Revision of Questions}

The results from the questions analysis with the total of 16 items, which were also used for the initial test, were developed according to the Multiple Intelligence criteria. The following Table 2 contains the Multiple Intelligence criteria used in developing basic chemistry questions in this study.

Table 2. Multiple Intelligence Criteria

\begin{tabular}{|c|c|c|}
\hline No. & Intelligences & Indicators \\
\hline 1 & Linguistic & $\begin{array}{l}\text { a. Proficient in vocabulary mastery } \\
\text { b. Make a speech and talk }\end{array}$ \\
\hline 2 & $\begin{array}{l}\text { Mathematics } \\
\text { Logic }\end{array}$ & $\begin{array}{l}\text { a. Do something systematically } \\
\text { b. Problems involving logic } \\
\text { c. Understand the pattern of cause } \\
\text { and effect } \\
\text { d. Count and play with numbers }\end{array}$ \\
\hline 3 & Visual and Spatial & $\begin{array}{l}\text { a. Having the right perception and } \\
\text { various angles } \\
\text { b. Graphical representation } \\
\text { c. Have high memory } \\
\text { d. Easily find your way in space }\end{array}$ \\
\hline 4 & Music & $\begin{array}{l}\text { a. Easily capture music } \\
\text { b. Sensitivity to sound and music } \\
\text { c. Know the structure of music well } \\
\text { d. } \quad \text { Creating music and melodies }\end{array}$ \\
\hline 5 & Interpersonal & $\begin{array}{l}\text { a. Easily recognize and distinguish } \\
\text { personal feelings of friends } \\
\text { b. Easy to work with friends } \\
\text { c. Be sensitive and empathize with } \\
\text { friends }\end{array}$ \\
\hline
\end{tabular}

\begin{tabular}{|c|c|c|}
\hline 6 & Intrapersonal & $\begin{array}{l}\text { a. Deep self-recognition } \\
\text { b. Self balance } \\
\text { c. Can concentrate well } \\
\text { d. Like working alone }\end{array}$ \\
\hline 7 & Kinesthetic & $\begin{array}{l}\text { a. Linking mind and body } \\
\text { b. Easy to express with the body } \\
\text { c. High body coordination and } \\
\text { flexibility }\end{array}$ \\
\hline 8 & Naturalist & $\begin{array}{l}\text { a. Recognize flora and fauna } \\
\text { b. Love nature } \\
\text { c. Understand well how the body } \\
\text { works }\end{array}$ \\
\hline
\end{tabular}

Format for developing questions was made according to Multiple Intelligence criteria arranged in that table. Based on the test analysis results of 32 questions, there were 16 valid questions (each 2 items) according to the Multiple Intelligence criteria. The results of the developed questions that can enhance students' Multiple Intelligence were then standardized by 3 experts. Each of them are experts from different area which are respectively an expert on the content, language and presentation. With standardization, the questions become easier for students to understand so they are more flexible in solving the questions. Standardization was carried out at the development stage. After both were done, then the esearchers proceed with the revision process in accordance with input from experts so that the question is feasible to use.

\subsection{Result on the Evaluation of Questions}

The revised questions from the three experts were given to students to find out and obtain data related to Multiple Intelligence. The data also taken from students' answers to the revised questions that they completed. This problem was also used as a final test (posttest) which aimed to see an increase in students' Multiple Intelligence in Basic Chemistry material. Based on these data, the frequency of the final student test scores can be seen in Table 3.

Table 3. Distribution of Student Final Test Scores

\begin{tabular}{lccc}
\hline \multicolumn{1}{c}{ Category } & Score & Frequency & Percentage (\%) \\
\hline High & $80-100$ & 57 & 95 \\
\hline Medium & $65-79$ & 3 & 5 \\
\hline Low & $<65$ & 0 & 0 \\
\hline
\end{tabular}

The data contained in Table 3 shows that there is an increase in Multiple Intelligence of FKIP students at Malikussaleh University. The final test results are classified into two categories which are high and medium with $95 \%$ belong to the high category and $5 \%$ of the medium category. That is, compared with the initial test 
results, the percentage of the frequency of students who are in the low category decreases from $70 \%$ to $0 \%$, in the moderate category decreases from $30 \%$ to $5 \%$, and in the high category increases from $0 \%$ to $95 \%$. These findings conclude that the ability of Multiple Intelligence of students increases well. This increase is indicated by the value of $\mathrm{N}$-gain. The following diagram shows a complete comparison of the pretest, posttest, and $\mathrm{N}$-gain Multi-Intelligence values shown in Figure 1.

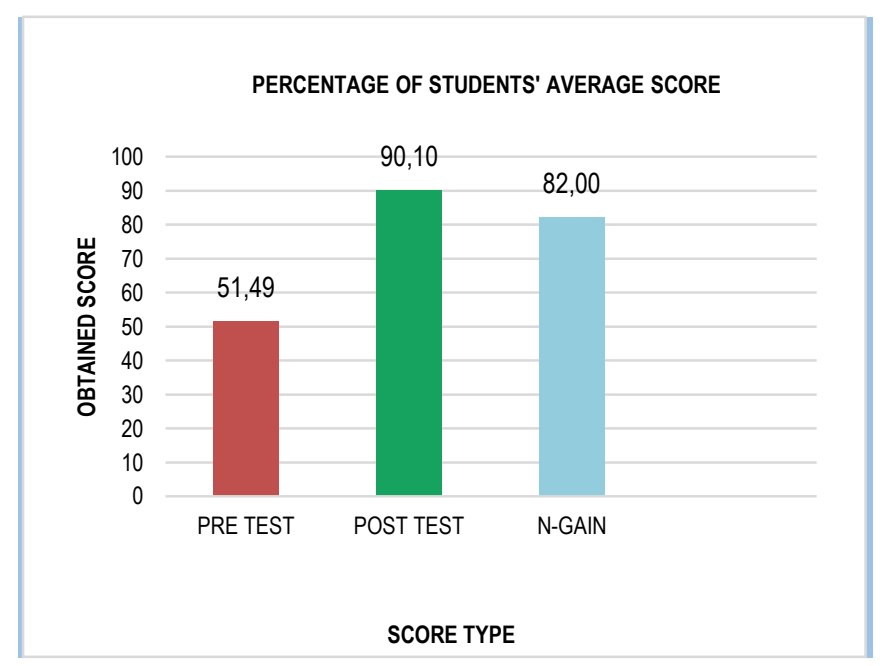

Figure 1. Comparison Diagram on Average Score

Percentage of Initial Test, Final Test, and N-gain Multiple

\section{Intelligence}

Based on the data obtained, it can be seen the extent of the increase in studnets' Multiple Intelligence by calculating the value of $\mathrm{N}$-gain. $\mathrm{N}$-gain value obtained is 0.82 which states that the value is in the high category (Meltzer, 2002). From this, it can be concluded that there is an increase in the Multiple Intelligence of students in Basic Chemistry by $82 \%$.

The final test results which are also used as evaluation material show that the questions used are really feasible because they are in accordance with the Multiple Intelligence criteria. In addition, the development of questions has also followed the stages to enhance students' Multiple Intelligence so that later they are ready to face the 4.0 era. This is in accordance with the eight items developed by Gardner for effective measurement of learning abilities. It was found that there is a positive relationship between Multiple Intelligence, learning ability and academic achievement in the context of students and because its uniqueness, it can lead to new avenues in teaching and learning. This is because eight items of Multiple Intelligence have a relationship with the personality of students so that it has a direct impact on their learning outcomes (Said and Budimanjaya, 2015).

\section{CONCLUSION}

Based on the research results and discussion, it can be concluded that:

1. The questions on Basic Chemistry material already contain questions that can develop Multiple Intelligence of FKIP students at Malikussaleh University.

2. There is an increase in Multiple Intelligence of FKIP students at Malikussaleh University as indicated by the percentage of $\mathrm{N}$-gain value of $82 \%$ which act as a preparation in facing the 4.0 era in Basic Chemistry courses

\section{REFERENCES}

Gardner, H. (1993). Multiple Intelligence The Theory in Practice a Reader, New York: Basic Book, A Subsidiary of Perseus Books, LLC.

Hidayat. (2011). Meningkatkan Kemampuan Berpikir Kreatif Matematik Siswa Menengah Atas Melalui Pembelajaran Kooperatif Think-Talk-Write (TTW), Prosiding Seminar Nasional Pendidikan Matematika STKIP Siliwangi Bandung, Volume 1 Tahun 2011.

Meltzer, D.E. (2002). The Relationship between Mathematics Preparation and Conceptual Learning Gains in Physics; a Possible Hidden Variable in Diagnostice Pretest Scores. American Journal Physics 70(12): 1259-1268.

Said, A. dan Budimanjaya, A. (2015). 95 Strategi Mengajar Multiple Intelligences. Jakarta: Kencana.

Sorenson. (1977). Psychology of Education. New York: Mc Graw-Hill, Inc.

Sukartono. (2018). Revolusi Industri dan Dampaknya Terhadap Pendidikan di Indonesia. Artikel. FIP PGSD Univesitas Muhammadiyah Surakarta, Jawa Tengah.

Tyler, L.E. (1956). The Psychology of Human Differences. New York; Appleton Company, Inc. 